\title{
A Note on Translation, Transliteration, and Abbreviations
}

All translations from Arabic are the author's unless otherwise noted. For transliterating words in Modern Standard Arabic, the text adopts a simplified system used by the International Journal of Middle East Studies. Diacritical marks have been omitted with the exception of the 'ayn (expressed by the symbol ') and the hamza ('). To reflect the social and cultural history of modern Egypt, the text preserves the colloquial forms of many words, for example, galabiyya and afandi instead of jalabiyya and effendi. Throughout, "the Company" and "the MSWC" refer to the Misr Spinning and Weaving Company in al-Mahalla al-Kubra. This usage honors the tradition of locals, who use the word al-Sharika (the Company) when talking about the MSWC.

Several important archives were utilized in writing this book. The main text, bibliography, and notes use the following acronyms:

ACD The Archive of the Corporation Department in the national archive known as Dar al-Wathaciq al-Qawmiyya (DWQ)

AMA The Archive of Mahafiz Abdin in the national archive known as Dar alWatha'iq al-Qawmiyya (DWQ)

DMU The national archive known as Dar al-Mahfuzat al-'Umumiyya

DWQ The national archive known as Dar al-Watha'iq al-Qawmiyya 
THIS PAGE INTENTIONALLY LEFT BLANK 
Industrial Sexuality 


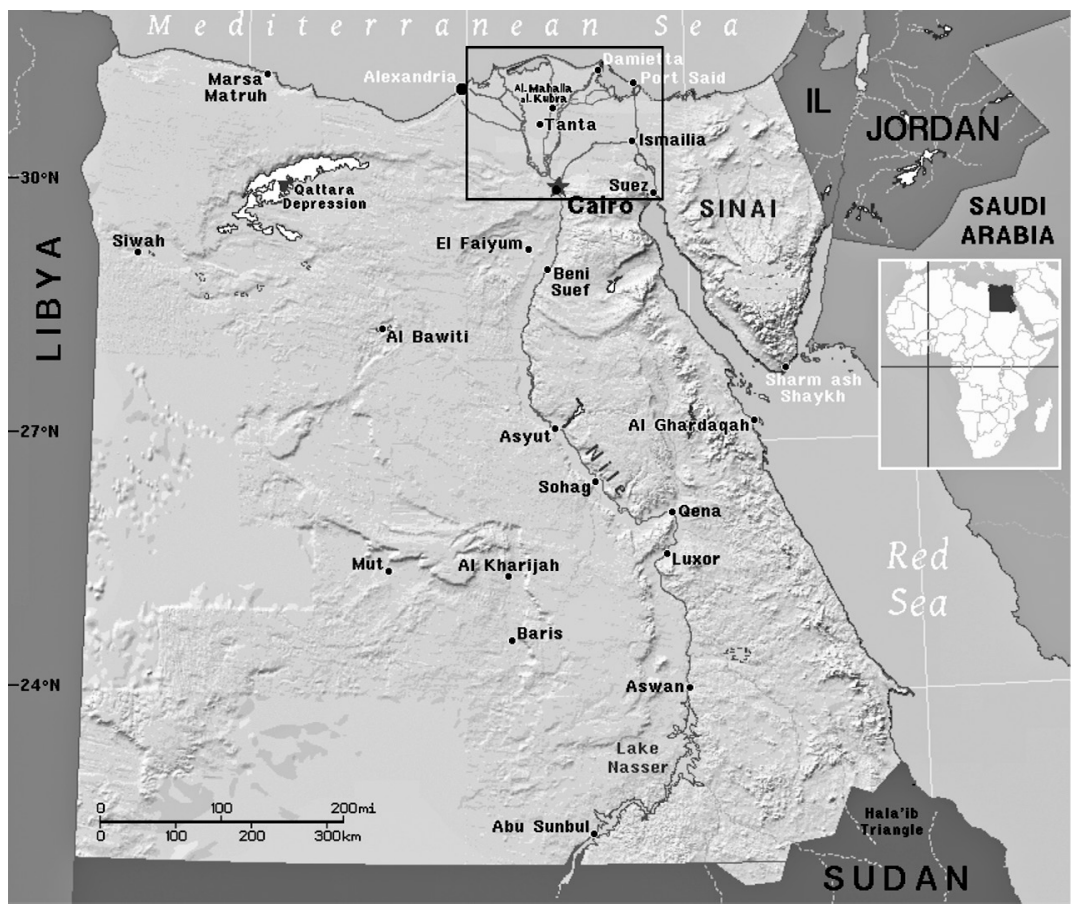

Map 1. A map of Egypt showing the location of al-Mahalla al-Kubra in the Delta. From WPClipart. 